\title{
A szívbetegek rehabilitációjának sportos arca
}

\author{
Apor Péter dr. \\ Országos Sportegészségügyi Intézet, Testnevelési Egyetem, Budapest
}

\begin{abstract}
A cardiorespiratoricus fittség (aerob kapacitás, $\mathrm{VO}_{2 \max }$ ) mértéke nagymértékben meghatározza az életkilátásokat, ezért növelése az egészség helyreállítására a szervezett edzésprogramon alapuló multidiszciplináris rehabilitáció egyik fó célja - a többi rizikótényező csökkentése mellett. A (tünetek által behatárolt) egyenletes iramú testmozgások mellett egyre kiterjedtebb az interval jellegú „edzés”. Ilyenkor a néhány perces intenzívebb szakaszt hasonló tartamú vagy hosszabb könnyư mozgás vagy passzív pihenő váltja (mérsékelt intenzitású interval edzés: MICE). Az intenzív szakasz történhet a tünetküszöb alatti maximális intenzitással is (high-intensity interval training: HIIT), sőt igen rövid, 10-30 másodperces szupramaximális és hosszabb pihenőszakaszok váltakozásával is (sprint interval training: SIT). Ezek előnye a 30-40\%-kal rövidebb edzéstartam, emellett sokak számára ezek elfogadhatóbb edzésformák, változatosabbá teszik a programot, hatásosabban, extra veszély nélkül. Az interval jellegü rehabilitációs edzésprogramok helyet kapnak az egyéb kórállapotok kezelésében is, káros mellékhatások nélkül.
\end{abstract} Orv Hetil. 2018; 159(33): 1346-1352.

Kulcsszavak: váltakozó intenzitású edzésterhelések a szívbetegeknek, mérsékelt intenzitású folyamatos edzés (MICE), nagy intenzitású interval edzés (HIIT), igen nagy (vágta-) intenzitású interval edzés (SIT), interval tréning egyéb kórállapotokban

\section{Cardiac rehabilitation and its sporty face}

The prognosis of cardiac and other diseases is highly determined by the level of cardiopulmonary fitness (aerobic capacity). The main purposes of rehabilitative activities include the restoration and increase of $\mathrm{VO}_{2 \max }$. The "classic" method is the continuous aerobic exercise (moderate-intensity continuous exercise). The higher increase of aerobic capacity in a shorter time can be developed by interval loads: shorter or longer active periods are interspersed by lowintensity rest periods. A recent form is the high-intensity interval training: $0.5-4$ minutes on $70-90 \%$ of the aerobic capacity followed by a rest or low-intensity biking/walking/jogging/any activity. The sprint interval training uses a few ten seconds of maximal intensity bursts changed with longer low-intensity activities. The advantages of the interval methods are shorter training time, less monotony, higher efficiency with not more risks. Interval training methods are applied also in other pathologies without disadvantages.

Keywords: interval training methods in cardiac rehabilitation, moderate-intensity cardiac exercise, high-intensity interval training, sprint interval training, advantages of intensive exercise in non-cardiac pathologies

Apor P. [Cardiac rehabilitation and its sporting face]. Orv Hetil. 2018; 159(33): 1346-1352.

(Beérkezett: 2018. március 16.; elfogadva: 2018. április 16.)

\section{Rövidítések}

$6 \mathrm{MWD}=$ hat perc alatt gyalog megtett méter; AV = atrioventricularis; $\mathrm{BMI}=($ body mass index $)$ testtömegindex; $\mathrm{BNP}=$ (B-type natriuretic peptide) B-típusú natriureticus peptid; $\mathrm{CABG}=$ (coronary artery bypass graft) koszorúér-áthidalás; $\mathrm{CAD}=($ coronary artery disease $)$ coronariaartéria-betegség; $\mathrm{CAT}=$ (continuous aerob training) folyamatos aerob edzés; $\mathrm{COPD}=$ (chronic obstructive pulmonary disease) krónikus obstruktív tüdőbetegség; FatMax = az az intenzitás, amelynél a zsíroxidáció a legmagasabb (spiroergometria); FFA = (free fatty acids) szabad zsírsavak; FMD $=$ (flow-mediated dilatation) véráramlás okozta értágulás; $\mathrm{HF}=$ (heart failure) szívelégtelenség; $\mathrm{HFmrEF}=$ (heart failure with mid-range ejection fraction) mid-range ejekciós frakciójú szívelégtelenség; HFpEF $=($ heart failure with preserved ejection fraction $)$ megtartott ejekciós frakciójú szívelégtelenség; $\mathrm{HFrEF}=$ (heart failure with reduced ejection fraction) csökkent ejekciós frakciójú szívelégtelenség; HIIT = (high-intensity interval training) nagy inten- 
zitású interval tréning; $\mathrm{HR}=$ (hazard ratio) kockázati arány; $\mathrm{HRV}=$ (heart rate variability) szívfrekvencia-változékonyság; MICE $=$ (moderate-intensity continuous exercise) mérsékelt intenzitású folyamatos edzés; MLHFQ $=($ Minnesota Living with Heart Failure Questionnaire) Minnesota kérdőív a szívelégtelenséggel élőknek; OUES = (oxygen uptake efficiency slope) az oxigénfelvétel gazdaságossága; $\mathrm{PCI}=$ (percutaneous coronary intervention) percutan coronariaintervenció; RPE = (rate of perceived exertion) a terhelés szubjektív nehézsége Borg-skála-értékkel; SCT = (speed circuit training) gyors köredzés, rezisztenciaedzés-fajta (fitnesz); SIT $=$ (sprint interval training) igen nagy (vágta-) intenzitású interval edzés; $\mathrm{VO}_{2 \max }$ = a test által maximálisan felvehetô és szállítható oxigén menynyisége

A rendszeres, kellő tartamú és intenzitású fizikai aktivitásnak, a nagyobb maximális oxigénfelvétellel jellemzett fittségnek több mint kéttucatnyi - nem mozgatószervi - betegségben preventív és gyógyító szerepe van [1-3]. A szívbetegek „esemény” utáni rehabilitációja csupán az egyik példa erre. A korábbi „szanatóriumi” rehabilitációt kiegészíti az „edzésprogramokon alapuló multidiszciplináris rehabilitáció" ambuláns formája, napjainkban az otthoni, testen viselt eszközökkel is irányított mozgásprogram - a telemedicina. Borbás és mtsai [4], Vértes és Szabados [5] nemrég áttekintették a megelőzésre és a rehabilitációra vonatkozó teendőket, amelyek hiánya magyarázza a korai ellátás kitûnő eredményeit követő igen kedvezőtlen kilátásokat a cardialis események után. A WHO és az egyéb autoritások által szorgalmazott heti legalább $5 \times$ fél óra mérsékelt intenzitású aktivitás fontosságát említik.

A hagyományos „óvatos”: egyenletes, mérsékelt intenzitású terhelések, úgymint gyaloglás, kocogás, gimnasztika, állóbiciklizés, társastánc [6] stb. - a moderateintensity continuous exercise: MICE - mellett az intenzívebb, a nagyobb hatású, a fitneszgyakorlatból is merítő, színesebb, sokak számára élvezetesebb edzés/ mozgás formák kerülnek be a rehabilitáció eszköztárába. A versenysportban alapvető interval edzés, a rezisztenciaedzés, újabban a nagy intenzitású interval tréning (HIIT), legújabban pedig a sprint interval training (SIT) találja meg a helyét a betegek aerob kapacitásának - fittségének - növelésében, a rizikófaktorok csökkentésében.

Az interval edzés a terheléses és a pihenő-/kisebb intenzitású szakaszok váltakozása. A „klasszikus” forma például 200-400 méter közel teljes intenzitású lefutása, majd 200-400 méter kocogva teljesítése, többször ismételve. A rehabilitációban 1-4 perces terhelések váltakoznak hasonló passzív vagy kis intenzitású pihenókkel. A versenysportból átvett „nagy intenzitású interval tréning” (HIIT) fél-egy perces intenzív és azonos vagy hosszabb pihenőszakaszokat jelent. A még rövidebb és az aerob kapacitásnak megfelelő terhelések és könnyebb szakaszok váltakozása vagy a 10-20 másodperces szupramaximális terhelések váltakozása a lazább szakaszokkal a sprint interval tréning. Ezek elve, hogy nagyon magas szintű izomanyagcsere és oxigénszállítás provokálható jelentôs tejsav-felszaporodás nélkül, mivel az anaerob alaktacid energia kerül lemerítésre és a pihenők alatt gyors helyreállítódásra aerob úton.

Természetesen betartandó a rehabilitációs edzések alapelve: előzetes terheléses vizsgálat, melynek alapján az edzés során a tünetet (angina, EKG-eltérés, abnormális vérnyomás-reakció, szubjektív jelek) kiváltó terhelésintenzitást legfeljebb tíz pulzusütésnyivel szabad megközelíteni. Tünetek híján a 220 - életkor maximális pulzusszámértékig is emelhető a terhelés, 5-6 edzés során fokozatosan közeledve ehhez az intenzitáshoz. Optimális esetben vezeték nélküli tele-EKG áll rendelkezésre, a hagyományos csoportos edzés során a teremben 1-2 tucat kerékpározó beteget folyamatosan EKG-monitoroznak az EKG-nörszök.

A csökkent ejekciós frakciójú szívelégtelen betegeken az edzés ellensúlyozza a progresszív vázizomvesztést, elősegíti a kamraremodellinget a cardiomegalia csökkentésével, az ejekciós frakció növelésével. A megtartott ejekciós frakciójú, gyógyszeres kezelésre alig javuló betegeken az edzés luzitrop hatású a bal kamra diasztolés funkciójára. A pulmonalis hypertoniások nyomásértékei csökkennek a rendszeres edzés hatására. Nagy intenzitású interval edzés (például $30 \mathrm{mp} \mathrm{100 \% -os} \mathrm{aerob} \mathrm{intenzi-}$ tással, $30 \mathrm{mp}$ nyugalom, tíz ismétléssel heti háromszor 45 percig 12 héten át) plusz rezisztenciaedzés folyt a 100 szívelégtelen (NYHA II-IV. stádiumú) betegen, közülük 72 fejezte be a vizsgálatot. Spiroergometria, SphygmoCor készülékkel pulzushullám-sebesség, tonometriás artérianyomás-mérés, echokardiográfia történt előtte-utána. Az edzést végzőkön csökkent a pulzushullám-sebesség 9\%-kal, az E/A arány 24\%-kal, a MLHFQpontszám 66\%-kal, a depressziópontszám 18\%-kal. Nőtt az augmentációs index 29\%-kal, a hatperces gyaloglástáv 13\%-kal, a $\mathrm{VO}_{2}$-csúcs 28\%-kal, a maximális teljesítmény pedig 25\%-kal [7].

Az Európai Kardiológus Társaság 2016. évi útmutatója a szívelégtelenség új osztályozását mutatta be: megtartott ejekciós frakciójú szívelégtelenség ( $\mathrm{HFpEF})$, ha az ejekciós frakció (EF) 50\%-nál nem kisebb; csökkent (HFrEF) a 40\% alatti érték, míg 2013 óta új kategória a 40-50\% közötti, mid-range ejekciós frakciójú szívelégtelenség (HFmrEF). Akut esetben a diagnózis a klinikai megjelenésen és a kezelés eredményességén alapul, a krónikus szívelégtelenség diagnózisa a klinikai megjelenésen, az anamnézisen és az EKG, az NT-proBNP szintjén alapul (normál: $125 \mathrm{pg} / \mathrm{ml}$ alatt) és a BNP-n (normál: $35 \mathrm{pg} / \mathrm{ml}$ alatt). Az echokardiográfia alapvetően fontos, további differenciálást tesz lehetővé. A gyógyszerek között újdonság az angiotenzinreceptor-neprilizin gátlók 8 (angiotensin receptor-neprilysin inhibitor, ARNI; szakubitril/valzartán) I/B indikációval a csökkent ejekciós frakciójú betegeknek. A Na-függő glükóztranszporter-2 (SGLT2)-gátló empagliflozin is javasolt a nagy kockázatú betegeknek a tüneti szívelégtelenség megelőzésére (IIa/B indikáció). A reszinkronizáció ke- 
zelésére (cardiac resynchronization therapy, CRT) új A/I indikáció a 150 ms-nél szélesebb QRS és balszárblokk, míg class IB indikáció a 130 ms-nél szélesebb QRS és balszár-blokk, valamint a nagyfokú AV blokk pacemaker-indikációval, a Life Vest áthidaló kezelés a magas kockázatú betegeknek IIb/C indikációval [8]. Mindezekhez tartozik a rehabilitáció. A megtartott ejekciós frakciójú szívelégtelen betegek gyógyszeres kezelése kevés eredményt hoz - számukra az edzésrehabilitáció a menedék. Vajon a HFmrEF-betegek hogyan reagálnak a neurohormonális blokádra? A komorbiditások agresszív kezelése eddig az egyetlen eredményességet ígérő eljárás - az edzés- - rehabilitáción kívül [9].

A szívbetegek aerob folyamatos vagy interval edzéséről áttekintést Pattyn és mtsai közleményében [10] olvashatunk, a témát az 2017 márciusáig megjelent 24 metaanalízis feldolgozásával tekintették át. Az 1080, átlagban 60 év körüli beteg az interval jellegű edzéssel $1,40 \mathrm{ml} / \mathrm{kg}$.perc-nyivel nagyobb $\mathrm{VO}_{2 \max }$-ot ért el - a coronariabetegek 1,25 , a szívelégtelenek $1,46 \mathrm{ml} /$ perc. kg-mal nagyobbat -, mint a folyamatos terhelésû́ edzéssel. Az első ventilációs küszöb és a maximális pulzusszám emelkedett nagyobb mértékben az interval edzést végzőkön. A rizikófaktorok, az életminőség egyformán javult.

Az edzésalapú rehabilitáció sarokkő a szívbetegek rehabilitációjában, a coronariabetegek halálozását 26\%-kal csökkenti. Egy ml/kg.perc aerobkapacitás-javulás 15\%kal növeli a túlélés esélyét.

A hagyományos edzésmód a tartós, egyenletes iramú/ intenzitású, 30-60 perces terhelés heti háromszor, 12 héten át. Azonban a nagyobb intenzitás nagyobb választ kelt - ezért vezették be az interval edzést az ezredforduló táján Norvégiában [11]. A metaanalízisek bizonyítják, hogy az interval edzés 1,04-2,14 ml/kg.percnyivel nagyobb aerobkapacitás-növekményt vált ki a szívbetegeken, rövidebb edzésidő alatt. Ez fontos szempont, ha az edzőhelyet egymás utáni csoportok használják. $\mathrm{A} \mathrm{VO}_{2 \max }$ mellett a pulzusmaximum, az oxigénpulzus, a ventilációs küszöb, az OUES (oxygen uptake efficiency slope), a $\mathrm{VE} / \mathrm{VO}_{2}$ slope, a pulzusnyugvás, a testtömeg, a vérnyomás, a lipidstatus, a szívmúködés-mutató ejekciós frakció, az érfunkció, az életminőség alakulására is kitérnek az elemzések. A 2592 tanulmányból 24-et, illetve 28-at ítéltek alkalmasnak az elsődleges és a másodlagos eredmények elemzésére. Az 1080 beteg egyik fele interval, másik fele folyamatos edzést végzett, a kimaradás 0-48\%, átlagban 12,4\%. Koruk 60 körüli, a NYHA-stádium II körüli. A heti 2-6, átlagban 3 edzést az interval során a csúcspulzusszám 90-95\%-ával, az egyenletes terheléssel 60-75\%-ával végezték, ami a pulzustartalékkal kifejezve 75-95\%, illetve 60-85\%. Tizenkét tanulmány mutatta, hogy az energiafelhasználás tekintetében azonosak voltak a folyamatos és az interval edzések. Az aerob kapacitás fejlődése tekintetében az interval edzés a hatásosabb $1,40 \mathrm{ml} / \mathrm{kg}$.perccel, a coronariabetegek 1,25, a csökkent ejekciós frakciójú betegek 1,46 ml/kg.percnyit javultak.
Az izokalorikus edzést végzők az interval edzéssel 2,08 $\mathrm{ml} / \mathrm{kg}$.percnyivel nagyobb javulást értek el. A maximális pulzusszám növelése mellett a verővolumen is nő, amit a nagyobb oxigénpulzus jelez. A másodlagos mutatók közül a ventilációs küszöb $0,88 \mathrm{ml} / \mathrm{kg}$.perccel nagyobb emelkedését váltotta ki az interval edzés, a maximális pulzusszám 3,78 ütés/perccel lett nagyobb, mint a folyamatos edzéssel elért növekmény. Az ejekciós frakciót az interval edzés növelte nagyobb mértékben, az artériafunkciót (FMD-t) hasonlóképpen. A 2,27\%-os FMDnövekedés jelentős, mivel 1\%-nyi javulás a cardiovascularis események 13\%-os csökkenésével jár. Az életminőséget oly sokféle módon jellemezték, hogy statisztika nem készíthető.

Egy közlemény tesz említést 3 órán belüli cardialis balesetről, ezenkívül említettek egy syncopét, egy pánikrohamot, egy halálesetet, amely nem az edzés kapcsán történt. Az edzés módjai - bicikli, gyaloglás-futás - hasonló fejlődést hoznak. Az elért magasabb aerob kapacitás a követő néhány vizsgálat szerint sok hónapig megmaradhat (ha az életmód erre hangsúlyt fektet).

Norwegian Ullevaal néven 2008-ban írták le a csoportos, nagy intenzitású interval edzésen alapuló szívrehabilitációs modellt a szívelégtelen betegek számára, amely heti háromszor 50 perc testgyakorlást és 15 perc konzultációt tartalmaz. Az intenzitást a maximális pulzus százalékával, a Borg-skálával és az aláfestő zene ritmusával irányítják. A zene hullámzó: a járás 100-108-as percpulzust vált ki, a cardiogyakorlatok három intenzitással, a futás (144-160-as pulzussal), a relaxáció 96-100-as pulzussal, a többi a köztes szívfrekvenciával történik. A svéd Friskis and Swettis modell volt az alapja: a zene, a mozgás öröme, a pozitív vezetés. A tartalma az izomzat fejlesztés-erősítés, a hajlékonyság és az állóképességi/fitnesz gyakorlatok. A zene a motiváló, a ritmusa hullámzik - 13 nóta a kísérő. A bemelegítés, az alacsony intenzitású terhelés, a hajlékonysági gyakorlatok, a levezetés a csúcspulzus 50-70\%-ával, 10-14-es RPE (rate of perceived exertion: Borg-skála)-érzéssel folyik; folyamatosan nő az intenzitás a csúcspulzus 70-85\%-áig, 14-16-os RPE-ig. Három, 3-4 perces intenzív, 85-90\%-os pulzust, 16-18as RPE-t okozó terhelés az intenzív szakasz - ez adja az 50 perces edzés három „púpját”. Az oslói Norwegian Sport Clinicben jelentkeznek a küldött betegek, ahol kétféle futószalag-protokollal mérik fel az aerob kapacitásukat. Ennek alapján $30 \mathrm{ml} / \mathrm{kg}$.perc alatti (vagy 60 év feletti) és 30 feletti aerob kapacitású csoportok alakulnak ki. 12-20 személy edz együtt, gyakorlott fizioterapeuta vezetésével. Hetente 2-3 új beteg csatlakozik. Az emócióikat a COOP-WONCA kérdőívvel tudakolják. Dietetikussal történő konzultációra is van lehetőség. A 12 hét során a $\mathrm{VO}_{2 \max } 31,6-$ ról $35,7 \mathrm{ml} / \mathrm{kg}$.percre nőtt, a maximális pulzus 159-ről 163-ra; 0,3 egységnyit csökkent a BMI, 4/2 Hgmm-t a vérnyomás [10]. A részt vevő betegek 15 hónappal a befejezés után kontrollra kerültek. Az 57 éves, 87\%-ban férfi páciensnek a kezdeti 31,9-ről 35,9-re javult az aerob kapacitása, 15 hónappal később 
$36,8 \mathrm{ml} / \mathrm{kg}$.perc lett az otthon folytatott heti átlagban 2,5 edzésalkalomnak köszönhetően, és ezzel párhuzamosan az életminőségjegyek is tovább javultak [12].

„Új” rehabilitációs edzésforma az aerob edzés kombinálása a rezisztenciaedzéssel circuit (köredzés) elrendezésben (amely a fitneszprogramokban évtizedek óta ismert). Speed circuit traininggel (SCT) és a folyamatos aerob edzéssel (CAT) egyaránt a pulzustartalék 60-85\%át használták - a folyamatos terhelés vette igénybe az alsóbb intenzitástartományt. Csak az SCT-edzés csökkentette az echokardiográfiás $\mathrm{E} / \mathrm{e}-\mathrm{t}$ és növelte az ejekciós frakciót és a $\mathrm{VO}_{2 \max }{ }^{-} \mathrm{ot}$, javította nagyobb mértékben az életminőséget. Jól viselték a betegek az SCT-edzést, biztonságosnak bizonyult [13].

\section{Rehabilitáció különböző cardialis betegségekben}

Otthoni rehabilitációval és diétás oktatással az 50\%-osnál kisebb ejekciós frakciójú szívbetegek a napi aktivitások szorgalmazásával 3 hónap alatt $2,7 \mathrm{ml} / \mathrm{kg}$.perc növekedést értek el az aerob kapacitásban, 421-ről 462 méterre nőtt a hatperces gyaloglástáv, 12,4-rôl 13,4 ml/kg.percre nőtt oxigénfelvétel mellett jelentkezett a spiroergometriás anaerob küszöb, javult az életminőség, 14-ról 5\%-ra csökkent a 90 napos kórházi újrafelvétel [14].

Az edzés mennyisége vagy az intenzitása a fontosabb a megtartott ejekciós frakciójú, stabil állapotú szívbetegeknek? A spironolakton versus placebo tanulmány 422 beteg részvételével zajlott - 52\% nő, átlagkor 67 év -, a heti, mozgással töltött óráit vallotta be. A 70 és 140 óra határokkal osztott 3 csoport hatperces gyaloglástávja (6MWD) arányos a mozgásmennyiséggel, de a $\mathrm{VO}_{2 \max }{ }^{-}$ mal nem. Akik nagy intenzitású tevékenységet végeztek heti legalább 8 órában, azokon mind a 6MWD, mind a $\mathrm{VO}_{2 \max }$ korrelált az aktivitással, a jobb funkcionalitással [15].

A tünetes szívelégtelen betegek, akiket szívátültetésre alkalmasság miatt vizsgáltak, HIIT-edzésben vettek részt: a 3-4 × egyperces $80 \%$-os intenzitású edzés $\left(\mathrm{VO}_{2}\right.$, illetve pulzustartalék százaléka), közben négyperces könnyű terheléssel, csökkentette a BNP-szintet 432-ról 254 pg/ml-re, erôsödött a combizom, korrelálva a hemoglobin-Alc-szinttel - a HIIT alkalmas edzésmódszer előrehaladott szívelégtelenség esetén [16].

A szívelégtelenségben szenvedő betegek életkilátásait a fizikai kapacitásuk jelzi; a transzplantáltak immunszupresszív kezelése növeli a fertőzések, a veseelégtelenség, a rák, vasculopathiák valószínűségét. A tízéves túlélés esélye $50 \%$ körüli. Az érfunkciók romlása nagyban függ a perifériától - a fizikai edzés ezen a ponton is javítja az életkilátásokat [17]. Újabban a szívtranszplantáltak körében is kedveltté vált a nagy intenzitású interval edzés (HIIT): rövidebb edzésidővel hatékonyabban növeli az aerob kapacitást, ami a várható túlélés jelzője. A hatásmechanizmusban az angiogenezis serkentése lehet az egyik fontos tényező, a gyulladásos mediátorok erre utalnak. A nagyobb terhelhetőség együtt jár a szorongás csökkenésével [17].

Stabil, nem szívelégtelen, kétszáz coronariabeteg egyik fele aerob folyamatos, másik fele aerob interval edzést végzett 3 hónapig. Kiinduláskor a magasabb $\mathrm{VO}_{2 \max }$ együtt járt a vékonyabb kamra-hátsófallal, a nagyobb ejekciós frakcióval, a kedvezóbb globális hosszanti strainnel, a kisebb E/e'-vel - ez utóbbi túnik a független előrejelzőnek. A három hónapos edzés normalizálta a kamrák közötti septumot, a bal kamra tágulását, növelte a verôvolument, de a többi mutató nem változott. A kamrák közötti septum vékonyodott fóleg a folyamatos edzést végzőkön, de nem volt egyéb változás a bal kamrai geometriában, a szisztolés vagy a diasztolés funkcióban [18]. Megemlítendő, hogy a stabil anginás betegek rehabilitációs edzésének eredményességéről kételkedő áttekintést írtak Long és mtsai Exeterből, az alkalmasnak talált hét közlemény, 581 beteg rehabilitációjának alapján [19]. A torontói rehabilitációs intézet tízéves CAD-beteganyagát tekintették át Lee és mtsai [20]. 772 beteg, $\left(\mathrm{VO}_{2 \max }: 20,8 \mathrm{ml} / \mathrm{kg}\right.$.perc) 12 hetes, heti öt, 60-80\%-os intenzitású MICE), illetve 772 beteg heti öt progresszív gyaloglás-kocogás edzést végzett $\left(\mathrm{VO}_{2 \max }\right.$ : $24,8 \mathrm{ml} / \mathrm{kg}$.perc). (A gyaloglás lendületes, $6,4 \mathrm{~km} /$ óra, a kocogás $8 \mathrm{~km}$ /óra sebességgel történt.) A koreai szívelégtelen, $40 \%$ alatti ejekciós frakciójú betegek egy centrumban, nem random módon a kórházban 60\%-os intenzitású edzésen vettek részt, míg mások otthonukban, fizioterapeuta vezetésével edzettek három hónapig. A kórházi csoport $\mathrm{VO}_{2}$-maximuma 19,4-ről 21,4-re nőtt, az otthon edzőké nem változott $(18,9-18,4)$. Egyéves követés során nem volt közöttük különbség a szíveseményekben [21]. Ezzel szemben azok, akiknek eleve alacsonyabb volt a fittségük, és a rehabilitációra nem javult legalább 6\%-nyit - a programban részt vevők $55 \%$-a tartozott ide -, nagyobb halálozási veszélynek és nem tervezett rehospitalizációnak vannak kitéve (HR: 2,15). Nemcsak az alacsony fittség, hanem a javítás képtelensége is rossz prognosztikai jel [22]. A CABG-n átesett betegek szívfrekvencia-variabilitása nagyobb mértékben javult a rehabilitációs, heti $5 \times 45$ perces bicikliző interval edzéstől, mint a PCI-ben részesülteké, persze a CAGBsek indulási HRV-értékei voltak a kedvezőtlenebbek az induláskor [23].

A bal kamrai assistkészülékkel élők is részt vehetnek a nagy intenzitású interval edzésben - állítják Ugata és mtsai a Jichi Orvosegyetemról, egy 6l éves, súlyos bal kamrai elégtelenséggel élő férfi nyolchetes HIIT-edzése során szerzett tapasztalataik alapján. Nőtt a terhelhetőség és az izomerő anélkül, hogy a balkamra-funkció romlott volna [24].

Tizenhárom felnőtt, született kombinált szívhibával, 12 hetes otthoni interval bicikliedzést végzett. Az állandó nehézségű terhelés ideje 12 perccel nőtt, a $\mathrm{VO}_{2 \max }$ 15\%-kal, a csúcsterhelés 20 wattal lett nagyobb [25].

Fallot-tetralógia miatt operált 36 felnőtt heti 2-3 HIIT-, illetve közepes intenzitású folyamatos edzésen 
vett részt hetente 2-3 alkalommal, összesen 36-szor. Az interval edzés növelte az aerob kapacitást 21,2-ről 22,7 $\mathrm{ml} / \mathrm{kg}$.perc-re, a flow mediálta értágulást 8,4-ról 12,9\%ra; csökkent a pulzushullám-sebesség 5,4-ról 4,8 m/mpre, az NT-proBNP 202-ről 190 ng/l-re, a fibrinogénszint 2,67-ről 2,46 g/l-re. A szívfrekvencia-variabilitást viszont a folyamatos edzés növelte hatásosabban, ahogyan az SF-36 mentális domainjét is [26]. A kezelt, 61 év körüli hypertoniás betegek hathetes HIIT-edzése (90 mp 90\%-os pulzustartalékkal - $120 \mathrm{mp}$ aktív pihenő, heti $3 \times 35$ percben) növelte az apelin és a NOx szintjét, míg az endothelin- 1 csökkent. Ez az edzés okozta vérnyomáscsökkenés mechanizmusának része lehet [27].

Meglepő tapasztalás, hogy a kis aortaaneurizma növekedését lassítja, ezzel a mútét szükségességét elodázza az edzés - feltehetően a vérnyomás csökkentése és az érfalfunkciók védése útján, írták japán szerzők [28].

A reszinkronizációs kezelésben részesültek többsége részesül a rehabilitációs edzésprogramokban, Olaszországban a résztvevők mintegy harmadát ók teszik ki [29].

A rehabilitációban részt vett szívbetegek 53\%-kal kisebb eséllyel halnak meg, 57\%-kal kisebb eséllyel a szívbetegségük miatt. Ennek ellenére csupán 33,7-35,5\%-uk vesz részt rehabilitációban [30].

\section{Interval edzés egyéb betegségek esetén}

Az interval jellegü terhelések COPD-ben kézenfekvőek; Porszasz és mtsai [31] sinus jellegü terhelésváltakozást vezettek be. A kanadai Nyberg és mtsai [32] azt vizsgálták, hogy az oxigénszúkében lévő $\left(\mathrm{FEV}_{1}\right.$ : 38\%) COPDseknek egy kézzel-két kézzel, kis terheléssel, de nagy ismétlésszámmal végzett rezisztenciaedzés gyakorlatai mekkora aerob terhelést jelentenek. A mozgások oxigénigénye testsúlykilogrammra számítva a COPD-seken nagyobb. Az egykezes gyakorlat nagy erókifejtést, de kisebb oxigénfelvételt vált ki, mint a kétkezes. A combon mért deoxihemoglobinváltozás egyforma a kétféle edzéssel, de a testsúlykilogrammra számított érték a COPDseken nagyobb - nagyobb a szöveti deoxigenizáció -, a vállhajlítás a combfeszítéssel összevetve több oxigént igényel: rosszabb az aerob hatásfok [32].

A pulmonalis bypertoniások gyaloglóedzése fitneszcentrumokban vagy otthon - járószalagon - a pulzustartalék 65-75\%-ával, heti $6 \times 45$ percig, 12 héten át, napi 6 gramm arginin bevétele mellett az endothelfunkció segítésére, 40 méterrel növelte a hatperces járástávot, 2 $\mathrm{ml} / \mathrm{kg}$.perccel a csúcs-oxigénfelvételt, gyorsította a pulzusnyugvást, emelte az anaerob küszöböt, csökkentette a fáradtságérzetet - nem kívánt esemény nélkül [33]. Nem meglepetés Kairóban sem, hogy a pulmonalis hypertoniásokon a légzés gazdaságossága (is) javul az ejekciós frakció javulása, a jobb kamrai nyomás csökkenése mellett [34].

35 feletti BMI-jü személyeket aerob kapacitásuk és adott terhelésen a zsírégetési arányuk (Fat Oxidation
Rates) alapján FatMax-intenzitással edző és HIIT-tel edző csoportra osztottak. Mindkét edzésmód növelte az aerob kapacitást és a maximális zsírégetést. Az inzulinrezisztencia (HOMA2-IR) csak a FatMax-intenzitással edzőkön javult, csak itt csökkent a nyugalmi FFA-szint [35].

A cukorbetegek heti három alkalommal 40 percnyit bicikliztek 50\%-os $\left(\mathrm{VO}_{2^{-}}\right)$intenzitással, illetve HIIT-edzést végeztek $10 \times 1$ perc $95 \%$-os terheléssel, egyperces pihenőkkel. Az aerob kapacitás 8, illetve 20\%-kal javult; az android testzsírt is a HIIT csökkentette, és a cukoranyagcsere mutatóit is a HIIT javította nagyobb mértékben. Az egyenletes terheléssel edzés az étkezést követő lipolysist növelte nagyobb mértékben. A HIIT hatékony, időtakarékos edzésmódszer [36]. 2-es típusú diabetes mellitusban a HIIT hatásosan csökkenti az artériás merevséget, a femoralis intima-media vastagságot, a nyugalmi pulzusszámot. Az egyesek szerint hatásosnak vélt eljárás, azaz a terhelést követő fehérjefogyasztás nem váltott ki további kedvező effektust [37].

Migrénesek (3,7 nap/hó) HIIT-edzése az augmentációs index - a pulzushullám-visszaverődés - az aorta merevsége - csökkenéséhez (22-rôl 14,9-re), a centrális szisztolés és diasztolés vérnyomás csökkenéséhez vezetett, nagyobb mértékben, mint az egyenletes edzés, és a migrénes napok száma csökkent [38].

A gyermekpopulációban is helye lehet a HIIT-edzésnek. Bond és mtsai 39 tanulmányt tekintettek át a cardiometabolicus mutatók javítására szánt közleményekből [39]. (A legtöbb labdajáték, a fogócska interval jellegü terhelést kíván, kellö szervezéssel és motivációval HIIT.) A kövér gyerekek HIIT-edzése - kontrollcsoportként MIC-edzése $-4 \times 4$ perces, $90 \%$ körüli pulzusszámmal, heti három alkalommal, illetve 44 perc $65 \%$ körüli pulzusszámmal - egyaránt normalizálta a bal kamra nyugalmi szisztolés szöveticsúcs-sebességét 1 , illetve $0,7 \mathrm{~m} /$ mp-cel [40].

Hír egy természetes interval jellegü sportmozgásról: a rekreációs labdarúgás heti $2 \times 1$ órában, 12-16 héten át megnövelte az aerob kapacitást 5-15\%-kal, csökkentette a vérnyomást 2-5 Hgmm-rel, illetve 6-8 Hgmm-rel a hypertoniásokon, 1-3 kg testzsírcsökkenést, lipidstatusjavulást hozott, növelte az alsó végtag ásványianyag-tartalmát - köszönhetően a magas pulzusszámot kiváltó, sok irányváltoztatást, gyorsítást-lassítást követelő, HIIT jellegú testmozgásnak, amely mind a cardiometabolicus, mind a mozgatórendszeri fittséget fejleszti. A labdarúgó programokba mellrákos nők bevonását tervezik [41].

A rehabilitáció lehetôségével élés minden országban elmarad a lehetőségektől, a szükségestől. Sunamura és $m$ tsai [42] Rotterdamban is panaszkodnak arról, hogy az akut szívinfarktus miatt végzett PCI után a 3871 , 2003 és 2011 között regisztrált betegből csak 39\% jelentkezett rehabilitációra, ámbár ezek négyötöde teljesítette a programot. 


\section{Következtetés}

Az utóbbi években „sportos” edzésmódszerek kapnak teret a szív- és egyéb betegek rehabilitációs tréningjében. $\mathrm{Az}$ interval jellegű nagyobb intenzitás révén rövidebb edzésidő alatt nagyobb mértékben javul a szív- és az endothelmúködés, a krónikus gyulladás, a rizikóstatus. A tolerálhatóságot - mint minden rehabilitációs tréningprogram előtt - terheléses vizsgálattal kell felmérni.

Anyagi támogatás: A közlemény megírása anyagi támogatásban nem részesült.

A szerző a cikk végleges változatát elolvasta és jóváhagyta.

Érdekeltségek: A szerzőnek nincsenek érdekeltségei.

\section{Irodalom}

[1] Apor P. Physical training against illnesses. [Testedzéssel a megbetegedések ellen.] Magy Tud. 2012; 12: 70-77. [Hungarian]

[2] Apor P, Nyakas Cs. Treatment of chronic diseases by sports. [A krónikus betegségek kezelése sportolással.] Sportorv Szle. 2008; 49: 104-108. [Hungarian]

[3] Pedersen BK, Saltin B. Exercise as medicine - evidence for prescribing exercise as therapy in 26 different chronic diseases. Scand J Med Sci Sports 2015; 25(Suppl. 3): 1-72.

[4] Borbás J, Forczek E, Sepp R, et al. Telecardiology: Tasks and duties of telemedicine. [Telekardiológia: A telemedicina feladatai és kötelességei.] Orv Hetil. 2017; 158: 1741-1746. [Hungarian]

[5] Vértes A, Szabados E. Cardiovascular prevention - 2016. [Cardiovascularis prevenció - 2016.] Orv Hetil. 2016; 157: 15261531. [Hungarian]

[6] Apor P. Dancing for health. [Társastánc az egészségért.] Orvostovábbk Szle. 2018, 25: 87-88. [Hungarian]

[7] Chrysohoou C, Angelis A, Tsitsinakis G, et al. Cardiovascular effects of high-intensity interval aerobic training combined with strength exercise in patients with chronic heart failure. A randomized phase III clinical trial. Int J Cardiol. 2015; 179: 269274.

[8] Oeing CU, Tschöpe C, Pieske B. Neuerungen der ESC-Leitlinien zur akuten und chronischen Herzinsufficienz 2016. Herz 2016; 41: 655-663.

[9] Hsu JJ, Ziaeian B, Fonarow GC. Heart failure with mid-range (borderline) ejection fraction: clinical implications and future directions. JAAC Heart Fail. 2017; 5: 763-771.

[10] Pattyn N, Beulque R, Cornelissen V. Aerobic interval vs continuous training in patients with coronary artery disease or heart failure: an updated systematic review and meta-analysis with a focus on secondary outcomes. Sports Med. 2018; 48:1189-1205.

[11] Nilsson BB, Lunde P, Holm I. Implementation and evaluation of the Norwegian Ullevaal model as a cardiac rehabilitation model in primary care. Disabil Rehabil. 2017 Nov 5: 1-8. doi:10.1080 109638288.2017.1397776. [Epub ahead of print]

[12] Nilsson BB, Lunde P, Grøgaard HK, et al. Long-term results of high-intensity exercise-based cardiac rehabilitation in revascularized patients for symptomatic coronary artery disease. Am J Cardiol. 2018; 121: 21-26.

[13] Dor-Haim H, Barak S, Horowitz M, et al. Improvement of cardiac dysfunction with novel circuit training method combining simultaneous aerobic-resistance exercises. A randomized trial. PLoS ONE 2018; 13: e0188551
[14] Chen YW, Wang CY, Lai YH, et al. Home-based cardiac rehabilitation improves quality of life, aerobic capacity, and readmission rates in patients with chronic heart failure. Medicine (Baltimore) 2018; 97; e9629.

[15] Bobenko A, Bartels I, Münch M, et al. Amount or intensity? Potential targets of exercise interventions in patients with heart failure with preserved ejection fraction. ESC Heart Fail. 2018; 5: 53-62.

[16] Taya M, Amiya E, Hatano M, et al. High-intensity aerobic interval training can lead to improvement in skeletal muscle power among in-hospital patients with advanced heart failure. Heart Vessels 2018; 33: 752-759.

[17] Yardley M, Gullestad L, Nytrøen K. Importance of physical capacity and the effects of exercise in heart transplant recipients. World J Transplant. 2018; 8: 1-12.

[18] Van De Heyning CM, De Maeyer C, Pattyn N, et al. Impact of aerobic interval training and continuous training on left ventricular geometry and function: a SAINTEX-CAD substudy. Int J Cardiol 2018; 257: 193-198.

[19] Long L, Anderson L, Dewhirst AM, et al. Exercise-based cardiac rehabilitation for adults with stable angina. Cochrane Database Syst Rev. 2018; 2: CD012786; doi: 10-1002/14651858.

[20] Lee LS, Tsai MC, Oh PI, et al. The effectiveness of progressive aerobic interval training in cardiac rehabilitation. Med Sci Sports Exerc. 2018; 50: 881-888.

[21] Kim M, Kim MS, Lim SJ, et al. Comparison of supervised hospital-based versus educated home-based exercise training in Korean heart failure patients. Korean Circ J. 2017; 47: 742-751.

[22] Bakker EA, Snoek JA, Meindersma EP, et al. Absence of fitness improvement is associated with outcomes in heart failure patients. Med Sci Sports Exerc. 2018; 50: 196-203.

[23] Szmigielska K, Szmigielska-Kaplon A, Jegier A. The influence of comprehensive cardiac rehabilitation on heart rate variability indices after CAGB is more effective than after PCI. J Cardiovasc Transl Res. 2018; 11: 50-57.

[24] Ugata Y, Wada H, Sakakura K, et al. High-intensity interval training for severe left ventricular dysfunction treated with left ventricular assist device. Int Heart J. 2018; 59: 216-219.

[25] Sandberg C, Hedström M, Wadell K, et al. Home-based interval training increases endurance capacity in adults with complex congenital heart disease. Congenit Heart Dis. 2018; 13: 254262.

[26] Novaković M, Prokšelj K, Rajkovič U, et al. Exercise training in adults with repaired tetralogy of Fallot: a randomized controlled pilot study of continuous versus interval training. Int J Cardiol. 2018; 255: 37-44.

[27] Izadi MR, Ghardashi Afousi A, Asvadi Fard M, et al. High-intensity interval training lowers blood pressure and improves apelin and NOx plasma levels in older treated hypertensive individuals. J Physiol Biochem. 2018; 74: 47-55.

[28] Nakayama A, Morita H, Nagayama M, et al. Cardiac rehabilitation protects against the expansion of abdominal aortic aneurisma. J Am Heart Assoc. 2018; 7: pii: e007959.

[29] Ambrosetti M, Sarzi Braga S, Giada F, et al. Exercise-based cardiac rehabilitation in cardiac resynchronization therapy recipients: A primer for practicing clinicians. Monaldi Arch Chest Dis. 2017; 87: 791.

[30] Fang J, Ayala C, Luncheon C, et al. Use of outpatient cardiac rehabilitation among heart attack survivors -20 States and the District of Columbia, 2013 and Four States, 2015. MMWR Morb Mortal Wkly Rep. 2017; 66: 869-873.

[31] Porszasz J, Rambod R, van der Vaart H, et al. Sinusoidal highintensity exercise does not elicit ventilatory limitation in chronic obstructive pulmonary disease. Exp Physiol. 2013; 98: 11021114.

[32] Nyberg A, Saey D, Martin M, et al. Cardiorespiratory and muscle oxygenation responses to low-load/high-repetition resistance 
exercises in COPD and healthy controls. J Appl Physiol (1985). 2018; 124: 877-887.

[33] Brown MB, Kempf A, Collins CM, et al. A prescribed walking regimen plus arginine supplementation improves function and quality of life for patients with pulmonary arterial hypertension: a pilot study. Pulm Circ. 2017; 8: 1-12.

[34] Mehani SH, Abdeen HA. Cardiopulmonary rehabilitation program impact on prognostic markers in selected patients with resting and exercise-induced ventilatory insufficiency: a clinical trial. J Phys Ther Sci. 2017; 29: 1803-1810.

[35] Lanzi S, Codecasa F, Cornacchia M, et al. Short-term HIIT and Fat $_{\max }$ training increase aerobic and metabolic fitness in men with class II an III obesity. Obesity (Silver Spring) 2015; 23: $1987-$ 1994.

[36] Winding KM, Munch GW, Iepsen UW, et al. The effect on glycemic control of low-volume high-intensity interval training versus endurance training in individuals with type 2 diabetes. Diabetes Obes Metab. 2018; 20: 1131-1139.

[37] Francois ME, Pistawka KJ, Halperin FA, et al. Cardiovascular benefits of combined interval training and post-exercise nutrition in type 2 diabetes. J Diabetes Complications 2018; 32: 226-233.

[38] Hanssen H, Minghetti A, Magon S, et al. Superior effects of high-intensity interval training vs. moderate continuous training on arterial stiffness in episodic migraine: a randomized controlled trial. Front Physiol. 2017; 8: 1086

[39] Bond B, Weston KL, Williams CA, et al. Perspectives on highintensity interval exercise for health promotion in children and adolescents. Open Access J Sports Med. 2017; 8: 243-265.

[40] Ingul CB, Dias KA, Tjonna AE, et al. Effect of high intensity interval training on cardiac function in children with obesity: a randomised controlled trial. Progr Cardiovasc Dis. 2018; Feb 13. pii: S0033-0620(18)30037-9; doi: 10.1016/j. pcad.2018.01.012. [Epub ahead of print]

[41] Krustrup P, Helge EW, Hansen PR, et al. Effects of recreational football on women's fitness and health: adaptations and mechanisms. Eur J Appl Physiol. 2018; 118: 11-32.

[42] Sunamura M, Ter Hoeve N, Geleijnse ML, et al. Cardiac rehabilitation in patients who underwent primary percutaneous coronary intervention for acute myocardial infarction: determinants of programme participation and completion. Neth Heart J. 2017; 25: 618-628.
(Apor Péter dr., Budapest, Czakó u 9., 1016 e-mail: p.apor.md@gmail.com

\section{Gyöngyös Város Önkormányzata Képviselő-testülete pályázatot hirdet}

Fogszabályozási feladatok ellátására

Gyöngyös városában, vállalkozási formában, határozatlan időre szóló feladatellátási szerződés keretében heti 16 órában, a Nemzeti Egészségbiztosítási Alapkezelö által kötött szerződés szerinti finanszírozással.

\section{Pályázati feltételek:}

- fogorvosi képesítés fogszabályozó fogorvos szakvizsgával,

- részletes szakmai önéletrajz,

- végzettséget igazoló okmányok másolata,

- OONYI másolata,

- 3 hónapnál nem régebbi erkölcsi bizonyítvány,

- hozzájárulás a pályázati anyag elbírálásában résztvevők betekintési jogához.

\section{A pályázat benyújtásának határideje:}

a felhívás megjelenésétől számított 15 nap.

\section{A pályázat elbírálásának határideje:}

a benyújtási határidőt követő soros Képviselö-testületi ülés.

\section{A pályázat benyújtásának módja:}

- postai úton, a pályázatnak a Gyöngyös Város Önkormányzata, Hiesz György polgármester részére (3200 Gyöngyös, Fő tér 13.) történő megküldésével,

- a kizárólag elektronikus úton történő jelentkezés érvénytelennek minősül.

\section{A feladat ellátásának időpontja:}

a feladat legkorábban 2018. december 1. napjától látható el.

\section{További felvilágosítás kérhetö:}

Polgármesteri Hivatal Közigazgatási és Intézményirányítási Igazgatóság: dr. Horváth Gábor igazgatótól a 06-37/510-329 telefonon vagy személyesen elözetes időpontegyeztetést követően. 